\title{
Maculopapular Rash Related to Atomoxetine: Case Report
}

\author{
Atomoksetin ile İlişkili Makülopapüler Döküntü: Olgu Sunumu
}

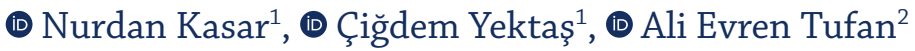 \\ ${ }^{1}$ Düzce University Faculty of Medicine, Department of Child Health and Diseases, Düzce, Turkey \\ ${ }^{2}$ Acıbadem University Faculty of Medicine, Department of Child and Adolescent Mental Health and Diseases, İstanbul, Turkey
}

Exanthematous drug eruptions, also known as maculopapular drug eruptions, are the most common drug-induced hypersensitivity reactions. Pruritus, urticaria, exanthematous rash, fixed drug eruption, photosensitivity, pigmentation and alopecia are common skin reactions to psychotropic medications. Atomoxetine (ATX), a selective inhibitor of presynaptic norepinephrine transporters (SNRI), is classified as a nonstimulant and is commonly used in the treatment of attention deficit hyperactivity disorder (ADHD). It also binds to dopamine and serotonin transporters with a low affinity. Abdominal pain, loss of appetite, somnolence, irritability, fatigue, dizziness and dyspepsia are the most common side effects of ATX. Major cutaneous drug reactions with SNRIs are rarely reported in the literature. Here we present an eight-yearold girl diagnosed with ADHD who had a drug-induced skin reaction after an increase in the dosage of ATX treatment.
\end{abstract}

Keywords: ADHD, atomoxetine, maculopapular eruption

Makülopapuler ilaç erüpsiyonları; ekzantematöz ilaç reaksiyonları olarak da bilinen en sık ilaç hipersensitivite reaksiyonlarıdır. Kaşıntı, ürtiker, ekzantematöz döküntü, fiks ilaç erüpsiyonları, fotosensitivite, pigmentasyon ve alopesi psikotrop ilaçlara karşı gelişen en sık deri reaksiyonlarıdır. Atomoksetin (ATX) selektif norepinefrin geri alım inhibitörü (SNRI) olup dikkat eksikliği hiperaktivite bozukluğu (DEHB) tedavisinde Gıda ve İlaç İdaresi onayı alan non-stimülan bir ilaçtır. Düşük affinitede dopamin ve serotonin taşıyıcılarına da bağlanmaktadır. Karın ağrısı, iştah azalması, somnolans, irritabilite, halsizlik, baş dönmesi ve dispepsi ATX'in en sık bildirilen yan etkileridir. Literatürde SNRI ilaçlar ile ortaya çıkan majör deri reaksiyonları nadir olarak bildirilmiștir. Bizim çalışmamızda DEHB tanısı olan ve ATX tedavisi sırasında doz artışı ile birlikte ilaca bağlı deri reaksiyonu gelişen 8 yaşında bir kız olgu sunulmuştur.

Anahtar Kelimeler: DEHB, atomoksetin, makülopapüler döküntü

\section{Introduction}

"Adverse drug reactions" (ADRs), according to the World Health Organisation, consist of all unwanted, deleterious reactions to a drug used for diagnosis, treatment or prophylaxis at an appropriate dose. ${ }^{1}$ ADRs may develop via immune or nonimmune mechanisms, and cutaneous ADRs are the most common form, comprising $10 \%-30 \%$ of all reactions. ${ }^{2}$ Clinically, cutaneous ADRs may lead to exanthema, urticaria/angioedema, drug eruptions, pustules, bullae, Stevens-Johnson syndrome/ Toxic Epidermal Necrolysis or cutaneous lupus. ${ }^{3}$

Attention deficit/hyperactivity disorder (ADHD) is a neurodevelopmental disorder characterised by impaired, persistent and age-inappropriate inattention, hyperactivity and/ or impulsivity. ${ }^{4}$ Atomoxetine, a selective norepinephrine reuptake inhibitor, is a non-stimulant agent frequently used to manage ADHD. The beneficial effects of atomoxetine are thought to be due to its actions in the prefrontal cortex and the absence of effects on serotonin or dopamine transporters. ${ }^{4}$
The most frequent side effects are reported to include stomach aches, reduced appetite, nausea/vomiting, somnolence, irritability, weakness, vertigo and dyspepsia. ${ }^{5}$ According to the manufacturer's information, cutaneous ADRs with atomoxetine may be observed in $2 \%$ of children. ${ }^{6}$ According to web surveys, rashes may develop in $1.5 \%$ of patients using atomoxetine (https://www.ehealthme.com/ds/atomoxetine/ rash/, accessed on 05.14.2019). Here, we report an 8-yearold female child with ADHD who developed maculopapular eruption while using atomoxetine. Informed consent was obtained from the parents.

\section{Case Report}

The patient was an 8-year-old female third grader who was brought to our department with complaints of "hyperactivity and non-compliance with chores and homework." The complaints, which were corroborated by her teachers, had been present for 6 years. She struggled academically, had poor spelling/writing

Address for Correspondence/Yazıșma Adresi: Nurdan Kasar MD, Düzce University Faculty of Medicine, Department of Child Health and Diseases, Düzce, Turkey

Phone: +90 5337803112 E-mail: nurdankasar@hotmail.com ORCID: orcid.org/0000-0002-3727-852X

Received/Geliș Tarihi: 16.01.2020 Accepted/Kabul Tarihi: 05.03.2020

${ }^{\circ}$ Copyright 2020 by the Turkish Association for child and Adolescent Psychiatry / Turkish Journal of Child and Adolescent Mental Health. published by Galenos Publishing House. 
and was rejected by her peers. Her developmental history was normal, except for having spoken her first words in her third year and forming sentences at 5 years. Her past medical history and family history were normal.

A baseline mental status examination revealed a hyperactive, inattentive female child with age-appropriate development. Parent and teacher forms supported ADHD, while a psychometric evaluation with the Wechsler Intelligence scale for Children-revised form revealed a total IQ of 76 with a 31-point difference between verbal and performance IQs. According to her history, examinations and tests, she was diagnosed with ADHD- hyperactive/impulsive presentation and a specific learning disorder (SLD) as per the DSM-5 criteria. ${ }^{4}$ A 4-week trial of methylphenidate $20 \mathrm{mg} /$ day in divided doses was not effective, and atomoxetine $25 \mathrm{mg}$ /day was started. Titration to $50 \mathrm{mg}$ /day was planned for the second week. However, the patient was brought to the department prior to titration due to a sudden eruption of diffuse, swollen rashes on her chest, back, shoulders and forearms. She was not using any other drugs at the time. Consultations from the Departments of Pediatrics and Dermatology were requested. Laboratory evaluations, including whole blood count, thyroid, renal and liver function tests, anti-nuclear antibodies, vitamin B12 and electrolytes, were within normal limits. The rashes were evaluated as exanthematous, maculopapular lesions (Figure 1) due to atomoxetine, and treatment was stopped. The rashes resolved spontaneously in the third week. Evaluation with the Naranjo et al. ${ }^{7}$ revealed a score of 7 (probable adverse reaction). Due to continuing symptoms of ADHD and SLD, she was started on methylphenidate osmotic-controlled release oral delivery system $18 \mathrm{mg} /$ day. Her symptoms benefited from this treatment, and she developed no adverse effects at the sixth month of treatment.
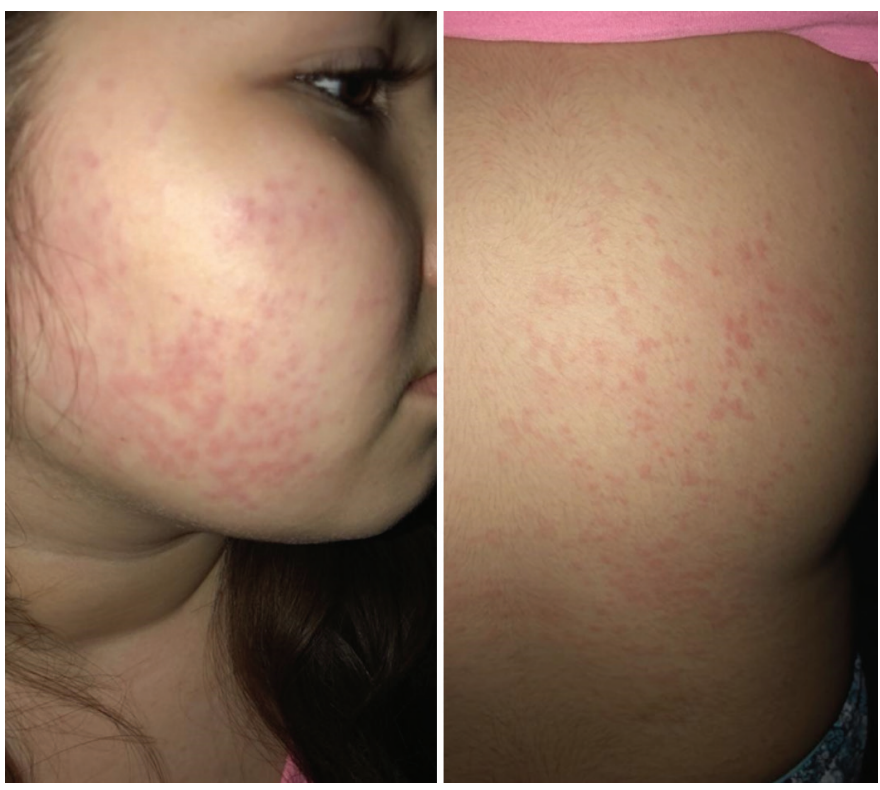

Figure 1. Exanthematous, maculopapular lesions on the face and body (an informed consent was obtained from the parents)

\section{Discussion}

Here, we report the development of diffuse exanthema (maculopapular rash) probably related to atomoxetine treatment in a prepubertal child with ADHD and SLD. Maculopapular eruptions due to drugs constitute the most common form of hypersensitivity reactions and may develop with anti-depressants, anticonvulsants, antipsychotics and other psychopharmacologic agents. ${ }^{1,3,8,9}$

Cutaneous ADRs with atomoxetine may be observed in $2 \%$ of patients. ${ }^{6}$ This rate is also reported in web-based surveys. According to previous studies. ${ }^{1,3,8,9}$, those reactions mostly occur in the first month of treatment, and many are thought to be due to delayed-type, T-cell-mediated immune reactions. Mild eosinophilia may be observed, and concomitant viral infections, co-medication with other drugs, disorders of the immune system and polymorphisms in the human leukocyte antigen alleles may increase the risk. In accordance with those reports, the rash developed at the end of the first week in our patient. However, neither eosinophilia nor any of the predisposing conditions were present. Evaluation with the Naranjo et al. ${ }^{7}$ revealed a probable relationship between rash and atomoxetine. Postmarketing reports of cutaneous ADRs related to atomoxetine are rare.$^{10}$ Bilgiç and Bilgiç ${ }^{10}$ reported a case of a female child with ADHD who developed localised depigmentation in the fourth week of treatment with atomoxetine. The authors posited that the depigmentation may be caused by catecholaminergic dysfunction leading to melanocyte destruction.

Our patient was deemed worthy of presentation due to the rarity of cutaneous $\mathrm{ADRs}$ with atomoxetine, which may even occur in the absence of predisposing risk factors.

\section{Ethics}

Informed Consent: Informed consent was obtained from the parents.

Peer-review: Externally and internally peer-reviewed.

\section{Authorship Contributions}

Concept: N.K., Ç.Y., A.E.T., Design: N.K., Ç.Y., A.E.T., Data Collection or Processing: N.K., Ç.Y., A.E.T., Analysis or Interpretation: N.K., Ç.Y., A.E.T., Literature Search: N.K., Ç.Y., A.E.T., Writing: N.K., Ç.Y., A.E.T.

Conflict of Interest: No conflict of interest was declared by the authors.

Financial Disclosure: The authors declared that this study received no financial support.

\section{References}

1. Beniwal R, Gupta LK, Khare AK, Mittal A, Mehta S, Balai M. Clinical Profile and Comparison of Causality Assessment Tools in Cutaneous Adverse Drug Reactions. Indian Dermatol Online J. 2019;10:27-33.

2. Arulmani R, Rajendran SD, Suresh B. Adverse drug reaction monitoring in a secondary care hospital in South India. Br J Clin Pharmacol. 2008;65:210-216.

3. Nayak S, Acharjya B. Adverse cutaneous drug reaction. Indian J Dermatol 2008;53:2-8. 
4. American Psychiatric Association. Diagnostic and Statistical Manual of Mental Disorders- Fifth Edition (DSM-5). American Psychiatric Publishing, Arlington, VA, 2013.

5. Garnock-Jones KP, Keating GM. Atomoxetine: a review of its use in attention-deficit hyperactivity disorder in children and adolescents. Paediatr Drugs. 2009;11:203-226.

6. Atomoxetine Prescribing Information. https://www.accessdata.fda. gov/drugsatfda_docs/label/2011/021411s035lbl.pdf. Accessed on 25.03.2019

7. Naranjo CA, Busto U, Sellers EM, Sandor P, Ruiz I, Roberts EA, Janecek E, Domecq C, Greenblatt DJ. A method for estimating the probability of adverse drug reactions. Clin Pharmacol Ther. 1981;30:239-245.

8. Mufaddel A, Osman OT, Almugaddam F. Adverse cutaneous effects of psychotropic medications. Exp Rev Dermatol. 2013;8:681-692.

9. Mitkov MV, Trowbridge RM, Lockshin BN, Caplan JP. Dermatologic side effects of psychotropic medications. Psychosomatics. 2014;55:120.

10. Bilgiç Ö, Bilgiç A. Possible atomoxetine-induced vitiligo: A case report. Atten Defic Hyperact Disord. 2015;7:179-181. 